\title{
The Effects of Political Stability in Local Currency Bond Markets
}

\author{
Kristin A. Van Gaasbeck \\ California State University, Sacramento \\ Taylor Marchelle \\ California State University, Sacramento
}

This study analyzes the effects of political stability, institutional quality, and event shocks on 1-year, 10year, and 30-year local currency bond yields. The data were collected from Bloomberg, IMF, World Bank, and OECD and cover 15 emerging market countries on a monthly frequency from January 2007 to February 2017. This study found that higher degrees of political stability and quality lead lower yields and lower default risk. Political event shocks such as party-changing elections lead to increased yields and default risk, while politically-motivated acts of violence affected the slope of yield curve.

Keywords: sovereign bond yields; political factors; emerging markets

\section{INTRODUCTION}

According to the Bank for International Settlements (BIS) data, local currency sovereign (government) debt increased from \$2,167 billion in March 2006 to \$5,438 billion in March 2016 measured in year 2006 dollars, which translates to over a 150 percent increase. Hard currency bonds are a common way for governments to finance debt because hard currencies are relatively safe and are widely accepted globally. However, in the event of a currency or debt crisis -- such as the Euro crisis in 2009 -emerging market countries could face financial ruin if their debt is solely financed by hard currencies. Local currency bonds are important because they represent a growing new asset class that increases investor portfolio diversification and allows emerging market governments to reduce exchange rate vulnerabilities (Arslanalp and Tsuda, 2014; Eichengreen, Hausmann and Panizza, 2007). Additionally, the International Monetary Fund suggests that developing local currency bond markets allows countries to better withstand volatility in capital flows, reduce reliance on foreign borrowing, and reduce current account imbalances.

Previous research has identified many possible factors that affect sovereign hard and local currency bond yields. These includes standard macroeconomic variables such as inflation, economic growth, debtto GDP ratio, exchange rates, policy rates, U.S. Treasury yields, and current account balance. This research combines these fundamental variables and incorporates a several indices of political quality and stability as well as variables to capture the occurrence of political/economic shocks, market beliefs, creditworthiness, global economic stability, market size, and overall risk.

This study is important because it further develops understanding of local currency bond markets through incorporating fundamental and political variables from the hard currency sovereign bond market 
literature with a model specification which focuses on local currency bond markets. In addition, we examine different measures of political climate: stability, institutional quality, and event shocks. By controlling for fundamental macroeconomic factors, we can better understand how political variables influence investor decisions in practice. Whether they choose to buy high-risk bonds to receive a high yield or purchase lower-yielding bonds that are relatively safe, including political stability into the yield analysis will provide an important factor to consider when making investment decisions because of its significant influence on yields.

This research focuses on the effects of political variables on a variety of interest rates. First, 10-year local currency yields are examined where through fixed-effects panel regression analysis; it was found that higher scores of political quality lead to lower yields. The same results are found when looking at 10year local currency yields relative to the 10-year U.S. Treasury yield. Finally, we examined how these fundamental variables and political quality variables affect the yield curve by observing their level and slope effects on 1-year and 30-year local currency yields. In this way, we consider not only level effects on yields, but potential slope effects associated with political stability.

\section{PREVIOUS WORK}

Despite its growing relevance, the local currency bond market is still relatively understudied. Sovereign debt markets are most commonly analyzed through the determinants of externally financed (hard currency) bond yields. Eichengreen, et al. (2007) outlined factors that may impede EM countries from issuing debt in their own currencies; mainly weak policies and institutions that contribute to weak economic growth and productivity. However, when a country is able to issue debt in its own local currency by maintaining economic and financial stability and creditworthiness, it may enhance the strength of the financial system and the economy as a whole. According to Eichengreen et al. (2007), the existence of a local currency bond market might alleviate currency mismatches: differences in the valuation of the foreign currency-denominated assets and liabilities on the balance sheets the entire economy - of households, firms, and the government. In other words, one major benefit to issuing local currency debt versus solely foreign-currency-denominated debt is that the valuation of debt is more easily managed by policy makers. Foreign currency-denominated debt is subject to changes in valuation depending on the financial and economic status of the country to which that currency belongs. Factors that influence yields include fiscal and financial stability, global economic stability, market expectations, foreign holdings in capital markets, and political stability. While an emerging market country may face higher local currency yields in the form of exchange rate risk premia required by global investors, the country benefits from reduced volatility in total external debt burden.

Financial and fiscal stability send signals about the strength of a country and its financial market. Jaramillo and Weber (2013) used a panel dataset of twenty-six emerging economies using monthly data between 2005 and 2011 to extend existing literature by examining the extent to which fiscal variables affect EM local currency bond yields. The fiscal variables they used included gross debt as a percentage of GDP, overall budget balance as a percentage of GDP, inflation rate, real GDP growth rate, domestic Treasury bill rate, U.S. 10-year bond yield, change in the stock market index, and foreign bond fund flows. They found that market sentiment (defined as beliefs about the current state and future health of a specific financial market) affects local currency bond yields. In other words, investors consider market volatility when deciding when and where to invest. Ferrucci (2003) also found a strong empirical relationship between macroeconomic fundamentals such as creditworthiness (liquidity) and local currency yields across twenty-three EM countries, indicating that risk and stability significantly influence investment decisions and therefore a country's entire debt market.

Global economic stability also plays a role in determining bond yields. Similar to Jaramillo and Weber (2013) that studied market sentiment for individual countries, Miyajima, Mohanty, and Chan (2015) broadened the scope to consider how global risk aversion might affect yields. They credited the increased interest of foreign investors in local bond markets to the demand for low risk, low volatility assets. Especially during times of global financial and economic hardship, investors tend to seek the safest 
assets that yield the highest return. While country-specific variables certainly affect investment decisions, global financial health can significantly affect a country's local currency bond market.

Foreign participation in local bond markets is particularly important to consider because foreign investors tend to engage in bond trading more than domestic investors (who tend to hold bonds to maturity), making the local bond market more liquid. Peiris (2013) contributed to the existing literature on EM bond markets by studying the impact of foreign participation on local currency bond yields and volatility by using a fixed effects panel model for ten EM countries. The regression results concluded that higher levels of foreign participation are associated with lower bond yields. Andritziky (2012) also found that bond yields are negatively associated with the amount of foreign investor holdings. The more government debt is financed by foreign investors, the lower yields become and the more liquid the market is. However, causation could be reversed: lower yields could attract more foreign investment due to the low-risk and low-volatility signal that low yields represent. Using a two-stage regression, the author concluded that foreign holdings follow the volatility of yields (safe assets attract more investment). The findings of both Andritziky (2012) and Peiris (2013) coincide with the findings of Eichengreen et al. (2007) and Jaramillo and Weber (2013) in that proving creditworthiness and financial and economic stability can enhance market sentiment and therefore attract more foreign investors. This suggests that any analysis of local currency yields must control for foreign investor participation and global economic conditions.

One of the main reasons to advocate for a local currency bond market is that a country can maintain better financial stability when its debt is not solely financed by a foreign currency. That is, a risk is associated with the behavior of another country's financial and economic volatility that may influence that currency. Presumably, the more debt is held by foreigners in their respective foreign currencies, the more vulnerable the country is to external financing and exchange rate shocks. Calvo and Talvi (2008) found sudden stops in external capital flows (the dumping of assets following a financial crisis in the investing country) are a significant risk in sovereign bond markets. Arslanalp and Tsuda (2014) also found these external funding shocks to significantly affect the level and volatility of EM bond yields. Ebeke and $\mathrm{Lu}$ (2015) used a fixed effects regression model to analyze the influence of foreign holdings of sovereign debt on yields in thirteen EMs from 2004 to 2013 (to account for the global financial crisis) and found that the investors' location significantly affects the volatility of bond yields, depending on the economic status of the investing the country.

Volatility and risk in the bond market can be determined in many ways; some are easily quantifiable (such as debt-to-GDP ratios) and others not so easily quantifiable (placing a value on a country's political structure and stability). Ferrari and Rolfini (2008) developed their own political risk index by compiling and weighting the degree of each subcategory of risk. They then ranked countries (both emerging and developed markets) and concluded that political risk plays a significant part in foreign investment decisions. Likewise, Baldacci, Gupta and Mati (2011) investigated how political and fiscal risks affect sovereign bond yields across forty-six EMs from 1997 to 2008. Using fixed effects, random effects, and instrumental variables, they concluded that heightened political and fiscal risk leads to higher bond yields. Stated simply, to compensate for increased risk, a risk premium must be paid in the form of higher yields.

Policy structure significantly affects political stability, and therefore yields. Sound policy structure is designed to control inflation, reduce volatility, reduce public and external debt, increase commodity prices, and increase capital flows, and therefore serves as a strong indicator of stability and low risk. Using the instrumental variables, Burger and Warnock (2006) analyzed the development of forty-nine local currency bond markets and found that policy structure and strength significantly matter in the determination of yields. Improvements in creditor rights and stable monetary policy (low inflation) can improve a country's local currency bond market by reducing volatility, and therefore attracting more investors from abroad. In related work, Burger, Warnock and Cacdac (2012) analyzed the local currency bond market with more recent data and found that macroeconomic stability and strong legal and creditor rights contribute to larger bond markets. Large bond markets tend to be more stable, which translates to a lower risk premium on yields. 
Similar to the work done by Burger and Warnock (2006), Ferrari and Rolfini (2008), Baldacci et al. (2011), and Burger et al. (2012) all which examine different elements of political stability and its effect on market attractiveness and bond yields, Eichler (2014) focused on examining political the determinants of EM sovereign bond spreads. Several facets of political stability were used, such as the type of the political system, the occurrence of elections, and a general political stability index. This granular approach to examining political stability shed light on which areas of political stability have the most significant effect. Through a fixed effects panel regression of twenty-seven EMs from 1996 to 2009, political strength and stability along with the quality and efficiency of the political and legal system proved to have the largest effect on lowering sovereign bond spreads. This study is comparable to Eichler (2014) in that a similar set of political stability variables will be used in a fixed effects panel model. However, the difference here is that we applied these variables to the local currency bond market versus the sovereign bond market.

Our work contributes to the sovereign debt literature in two ways. First, we combine macroeconomic variable from earlier work to model the behavior of local currency bond markets. Second, we consider the importance of different political variables measuring stability, quality, and events, previously absent from the literature on local currency bond yields. This study examines fifteen EMs, using monthly data from January 2007 to February 2017 on major macroeconomic fundamental variables, including: generic local currency yields (yield-to-maturity), U.S. Treasury yields (yield-to-maturity), industrial production, exchange rate, CPI inflation, policy rates, debt-to-GDP ratio, current account balance as a percentage of GDP, budget balance, the World Bank's Governance Indicator indices, and dummy variables for the occurrence of political conflicts and party-changing elections. To control for shocks, we quantified the occurrence of political conflict, party-changing elections, and accounted for the global financial crisis. To control for creditworthiness, we focus only high-functioning, investment-grade markets. To measure political risk, policy structure, and creditor rights, this study employed the scores given to each country by the World Bank's Governance Indicators. The approach will be most similar to that of Eichler (2014); however, this research will focus on the EM local currency bond market instead of only EM sovereign bond (hard currency) spreads. We examine panel data with time and country fixed effects. The expected results are similar to all of the aforementioned studies in that instability (here, political instability in particular) causes yields to rise as a result of the rising risk premium. We also consider how political instability affects the term structure of interest rates.

\section{DATA AND METHODOLOGY}

The data were collected from Bloomberg, World Bank, International Monetary Fund (IMF), and OECD on a monthly basis from January 2007 to January 2017. The countries in the dataset include Brazil, Chile, Czech Republic, Hungary, Indonesia, Korea, Malaysia, Mexico, Peru, Philippines, Poland, Russia, South Africa, Taiwan, and Turkey. The fundamental macroeconomic variables used are 10-year, 1-year, and 30-year bond yields (issued in local currencies), industrial production, CPI, policy rates, debtto-GDP ratio, current account balance (CAB), budget balance, USD to local currency exchange rates, and 10 -year U.S. treasury yields. Industrial production and CPI were measured as percentage changes to capture economic growth and inflation, while debt-to-GDP and current account balance are measured as a percentage of GDP. The summary statistics reported in Table 1 indicate considerable variation in local currency yields and political stability measures in our sample.

This research will employ several subcategories of political stability and political shocks. To account for quality of governance, the World Bank's Worldwide Governance Indicator dataset was used. This dataset scores each country on six dimensions of governance: Political Stability, Control of Corruption, Regulatory Quality, Rule of Law, Voice and Accountability, and Government Effectiveness. All six categories of governance were included as each individually affects overall government stability and

quality. These six governance indices represent indicators of market sentiment. As each score is made publicly available, the scores should assist investment decisions. 
TABLE 1

SUMMARY STATISTICS

\begin{tabular}{l|cccc}
\hline \multicolumn{1}{l}{} & Mean & Min & Max & $\begin{array}{c}\text { Standard } \\
\text { Deviation }\end{array}$ \\
\hline 10-year Yield & 6.13 & 0.22 & 17.26 & 3.01 \\
1-year Yield & 4.00 & -1.12 & 16.68 & 2.77 \\
30-year Yield & 7.05 & 1.48 & 13.25 & 2.99 \\
Growth & 0.69 & -29.2 & 17.87 & 3.45 \\
Debt & 31.14 & -19.28 & 63.80 & 16.76 \\
Inflation & 2.15 & -2.28 & 13.7 & 2.72 \\
CAB & 0.56 & -8.98 & 17.96 & 5.20 \\
BB & -2.11 & -10.30 & 7.41 & 2.51 \\
Policy Rate & 5.31 & 3.29 & 0 & 15.00 \\
Exchange Rate & 845.90 & 1.16 & 14,653 & $2,671.53$ \\
UST 10Y & 2.77 & 1.45 & 5.02 & 0.91 \\
UST 1Y & 0.74 & 0.086 & 3.34 & 1.05 \\
UST 30Y & 3.02 & 2.18 & 3.97 & 0.42 \\
Fed Funds Rate & 0.843 & 0.07 & 5.26 & 1.52 \\
Political Stability & 48.15 & 14.61 & 72.77 & 15.28 \\
Control of Corruption & 50.93 & 28.44 & 81.46 & 12.21 \\
Government Effectiveness & 60.67 & 39.75 & 78.20 & 10.19 \\
Rule of Law & 54.31 & 30.96 & 78.61 & 13.98 \\
Regulatory Quality & 60.87 & 39.55 & 80.93 & 11.06 \\
Voice and Accountability & 56.63 & 28.50 & 73.27 & 11.57 \\
\hline
\end{tabular}

The Political Stability (PS) index captures the likelihood of political instability and politically motivated violence or terrorism. Variables included in this index rubric are social unrest, violent demonstrations, armed conflict, international tensions and terrorist threat, protests and riots, civil war, and internal conflict driven by religious or ethnic motives. Political stability is connected to long-term economic growth, which in itself is a fundamental part of lowering default risk. Control of Corruption captures how well each country controls corruption in the form of using political power in the form of private gain. Factors in this index are corruption among public officials, trust in politicians, diversion of public funds and irregular payments to public sector departments. The Regulatory Quality index measures a government's ability to create laws that encourage private sector development. This index examines price controls, unfair competitive practices and excessive protections, discriminatory tariffs and taxes, trade barriers, anti-trust policies, investment and financial freedom, strictness of environmental regulations, and ease of starting a business. Rule of Law accounts for the degree to which citizens abide by laws and rules of society, as well as the quality of property rights and law enforcement. This accounts for violent and organized crime levels, fairness and speediness of judicial system, property rights and protection, and confidence in and reliability of law enforcement and judicial system. Voice and Accountability captures the extent to which citizens are able to participate in electing their government officials, as well as their degree of free speech, free media, and free expression. This index also accounts for political, civil, and human rights, as well as transparency and accountability of public officials. The Government Effectiveness index captures the quality of public and civil service along with its separation from political pressures, and the formulation, implementation, and credibility government policies. Included in this index valuation rubric is the quality of public education, roads, infrastructure, public transportation system, healthcare services, as well the quality of bureaucracy. ${ }^{1}$

Shocks are measured as election and political conflict events. Elections were measured as a binary variable and the data were gathered from the World Bank's Database of Political Institutions. This 
variable will capture the elections that warrant a change of political party. Conflict data were collected from the Political Instability Task Force and captures the periods in which political violence or terrorism erupts. Both election and conflict will be measures as a binary variable where the occurrence of an election (or conflict) was given a " 1 " and " 0 " if otherwise

The second section of the analysis examines the effects of the aforementioned explanatory variable on default risk, which was calculated as the difference between the 10-year local currency and 10-year U.S. Treasury yields. The third and final section of the analysis section examines the effect of the explanatory variables on the slope and shape of the yield curve. Here, two separate dependent variables were created to measure the slope of the yield curve: 10-year yield minus 1-year yield, and 30-year yield minus 10-year yield. The third section also adds the 1-year U.S. Treasury yield and the 30-year U.S. Treasury yield as explanatory variables. All the data used to form the new dependent variables from the second and third sections of the regression analysis were also reported on a monthly basis and were collected from Bloomberg.

We conduct a panel data analysis by using a pooled OLS regression with robust standard errors first, then using time and entity fixed effects models. The following model specification is used:

$y_{i t}=\alpha+\sum_{j=1}^{J} \beta_{j i t} x_{j i t}+\sum_{k=1}^{K} \gamma_{k i t} G_{k i t}+\delta_{t} U_{t}+\varepsilon_{i t}$

where the dependent variable $y$ represents local currency 10-year bond yields (yield to maturity) of country $i$ at time $t, \alpha$ is an intercept coefficient, the $x_{j}$ 's are the set of $J$ fundamental macroeconomic explanatory variables, $G_{k}$ 's are the set of $K$ governance and shock variables, $U_{t}$ is the U.S. Treasury yield, and $\varepsilon$ are the i.i.d. error terms The fundamental macroeconomic variables included are economic growth from month-on-month percentage change in industrial production, CPI inflation, policy rates, debt-toGDP ratio, current account balance as a percentage of GDP, budget balance as a percentage of GDP, local currency to USD exchange rate, and the Federal funds rate. The governance and shock variables included are the six governance indices and two separate binary variables capturing the occurrence of partychanging elections and political conflict. We use this same specification to model the 1- and 30-year local currency yields.

In order to examine local currency default risk, we adopt the following specification:

$d_{i t}=\alpha+\sum_{j=1}^{J} \beta_{j i t} x_{j i t}+\sum_{k=1}^{K} \gamma_{k i t} G_{k i t}+\varepsilon_{i t}$

where $d_{i t}=y_{i t}-U_{t}$. This specification allows us to focus on the importance of macroeconomic fundamentals and political risk on default risk premia.

To understand how these variables affect the slope of the yield curve, we use the following specification:

$c_{i t}=\alpha+\sum_{j=1}^{J} \beta_{j i t} x_{j i t}+\sum_{k=1}^{K} \gamma_{k i t} G_{k i t}+\delta_{t} S_{t}+\varepsilon_{i t}$

where $S_{t}$ is the slope of the U.S. Treasury yield curve and $c_{i t}$ is the slope of the yield curve for country $i$ at time $t$. The slope of the yield curve is measured for the short and long ends of the yield curve. We measure $c_{i t}$ as the difference between the 10-year and 1-year local currency yields (short end), and the difference between the 30-year and the 10-year local currency yields (long end).

Industrial production should have a negative relationship with yields because economic growth is an indication of a country's stability and prosperity, thereby mitigating risk and lowering yields. Inflation should be positively related to yields because inflation causes bonds to lose value by increasing the risk premium paid that compensates for value lost through inflation. We expect a positive relationship between policy rates and local currency yields. Debt-to-GDP should have a positive effect on yields as increased debt in relation to GDP increases investment risk. The relationship between current account balance as a percent of GDP and yields should be positive because a positive account balance (surplus) 
indicates that the country is a lender to the world, which decreases investment risk. Budget balance should have a negative effect on yields; yields should fall as the budget balance becomes more positive (surplus) due to decreased risk, and similarly, yields should increase as the budget balance becomes more negative (deficit) due to increased risk. U.S. Treasury yields should have a positive relationship with 10-year local currency yields because U.S. Treasury yields are used as a proxy for many other securities and they tend to be a good indicator of investor confidence. The exchange rate variable should have a positive relationship with yields fluctuating exchange rates induce a currency mismatch risk for foreign investors. The governance indices should all have a negative relationship with yields as a higher index score represents a more stable and effective government. The governance index variables should be negatively related to yields and risk, while elections and conflict, should both have a positive relationship with yields and risk.

\section{RESULTS}

Results from the specifications above are report in Tables 2-4. Table 2 reports estimates from pooled OLS, country-only fixed effects, and country and time fixed effects regressions. Regression IV shows the same time and country fixed effects model less the insignificant governance and political event shock variables. Regression IV is the preferred model, but alternative specifications are included for robustness. ${ }^{2}$ Across Regressions I though IV, growth (as accounted for my monthly percent change in industrial production) has the expected sign on each coefficient, however, it is only statistically significant in Regression I. The results from Regression I indicate a 1 percentage point increase in economic growth decrease yields by 0.04 percentage points, or in other words, 4 basis points. Debt-to-GDP is highly significant in three of the four regressions. CPI inflation is only significant in the entity-only fixed effects model, Regression II. As expected, inflation has a positive relationship with yields. Current account balance as a percent of GDP, policy rate, and budget balance as a percent of GDP all are significant across Regressions I though IV and all have the expected signs on each coefficient. While the exchange rate may be highly significant across each regression, it does not have a large impact on yields, given the magnitude of its coefficients. The 10-year U.S. Treasury yield (UST) and the federal funds rate both are highly significant across each regression and have the expected signs on their respective coefficients.

Political stability is significant across each model. The results in Regression IV can be interpreted as the following: a 1 percent increase in the Political Stability score brings about 2.54 percentage point decrease in yields (or a 254 basis point decrease). This inverse relationship is expected and is proved throughout Regressions I through IV: a higher Political Stability score should represent a more stable and efficient country, which should ultimately be associated with lower yields. The Control of Corruption and Voice and Accountability variables also significant across each regression and shows the expected inverse relationship with yields. These results show that as a country has better control of government corruption, more trustworthy politicians, and higher degrees of democracy and human rights, yields should be lower on average. The coefficients on each instance of Rule of Law are significant in three of the four regressions; however, the significant estimated coefficients do not show an inverse relationship with yields, as expected. While the Government Effectiveness and Regulatory Quality measures are insignificant in the panel fixed effects models, they did have the expected inverse relationship with yields. The results indicate that the occurrence of a presidential or parliamentary election where the presiding political party changes does have a positive and strongly significant effect on yields. For example, the results from Regression IV indicate that the occurrence of a party-changing election will increase yields on average by about 0.4 percentage points ( 40 basis points). This concurs with the underlying theory that a change of political regime can cause instability, which directly affects risk and therefore yields. 


\section{TABLE 2 \\ REGRESSION RESULTS FOR YIELD CURVE LEVEL EFFECTS}

Dependent Variable: Local Currency 10-Year Bond Yields

\begin{tabular}{|c|c|c|c|c|}
\hline & $\begin{array}{c}\text { (I) } \\
\text { Pooled OLS }\end{array}$ & $\begin{array}{c}\text { (II) } \\
\text { Entity Fixed Effects }\end{array}$ & $\begin{array}{c}\text { (III) } \\
\text { Two-Way Fixed } \\
\text { Effects }\end{array}$ & $\begin{array}{c}\text { (IV) } \\
\text { Two-Way Fixed } \\
\text { Effects }\end{array}$ \\
\hline Growth & $\begin{array}{c}-0.044 * * * \\
(0.014)\end{array}$ & $\begin{array}{l}-0.002 \\
(0.007)\end{array}$ & $\begin{array}{l}-0.006 \\
(0.007)\end{array}$ & $\begin{array}{c}-0.006 \\
(0.007)\end{array}$ \\
\hline Debt-to-GDP & $\begin{array}{c}-0.037 * * * \\
(0.002)\end{array}$ & $\begin{array}{c}0.003 \\
(0.006)\end{array}$ & $\begin{array}{c}0.021^{* * *} \\
(0.006)\end{array}$ & $\begin{array}{c}0.022 * * * \\
(0.005)\end{array}$ \\
\hline Inflation & $\begin{array}{l}-0.014 \\
(0.015)\end{array}$ & $\begin{array}{c}0.039^{* *} \\
(0.020)\end{array}$ & $\begin{array}{l}-0.015 \\
(0.021)\end{array}$ & $\begin{array}{l}-0.016 \\
(0.021)\end{array}$ \\
\hline $\mathrm{CAB}$ & $\begin{array}{c}-0.174 * * * \\
(0.008)\end{array}$ & $\begin{array}{c}-0.058^{* * *} \\
(0.009)\end{array}$ & $\begin{array}{c}-0.056^{* * * *} \\
(0.009)\end{array}$ & $\begin{array}{c}-0.056^{* * * *} \\
(0.009)\end{array}$ \\
\hline Policy Rate & $\begin{array}{c}0.304 * * * \\
(0.027)\end{array}$ & $\begin{array}{c}0.376^{* * *} \\
(0.018)\end{array}$ & $\begin{array}{c}0.345^{* * *} \\
(0.019)\end{array}$ & $\begin{array}{c}0.346^{* * *} \\
(0.018)\end{array}$ \\
\hline Budget Balance & $\begin{array}{c}-0.135 * * * \\
(0.015)\end{array}$ & $\begin{array}{c}-0.086^{* * *} \\
(0.014)\end{array}$ & $\begin{array}{c}-0.086^{* * *} \\
(0.015)\end{array}$ & $\begin{array}{c}-0.086^{* * * *} \\
(0.014)\end{array}$ \\
\hline Exchange Rate & $\begin{array}{l}-0.00004^{*} \\
(0.00002)\end{array}$ & $\begin{array}{c}0.0003^{* * * *} \\
(0.000)\end{array}$ & $\begin{array}{l}0.0003 * * * \\
(0.00004)\end{array}$ & $\begin{array}{c}0.0003 * * * \\
(0.000)\end{array}$ \\
\hline UST & $\begin{array}{c}0.876 * * * \\
(0.055)\end{array}$ & $\begin{array}{c}0.807 * * * \\
(0.038)\end{array}$ & $\begin{array}{c}1.700 * * * \\
(0.479)\end{array}$ & $\begin{array}{c}1.715^{* * *} \\
(0.478)\end{array}$ \\
\hline Fed Funds Rate & $\begin{array}{c}-0.244 * * * \\
(0.034)\end{array}$ & $\begin{array}{c}-0.317^{* * *} \\
(0.024)\end{array}$ & $\begin{array}{c}-0.825^{* * *} \\
(0.295)\end{array}$ & $\begin{array}{c}-0.833^{* * *} \\
(0.292)\end{array}$ \\
\hline Political Stability & $\begin{array}{c}0.942 * * * \\
(0.171)\end{array}$ & $\begin{array}{c}-3.370 * * * \\
(0.263)\end{array}$ & $\begin{array}{c}-2.580 * * * \\
(0.260)\end{array}$ & $\begin{array}{l}-2.544 * * * \\
(0.252)\end{array}$ \\
\hline $\begin{array}{l}\text { Control of } \\
\text { Corruption }\end{array}$ & $\begin{array}{l}1.025^{*} \\
(0.555)\end{array}$ & $\begin{array}{c}-2.440 * * * \\
(0.525)\end{array}$ & $\begin{array}{c}-2.891 * * * \\
(0.516)\end{array}$ & $\begin{array}{c}-2.957 * * * \\
(0.476)\end{array}$ \\
\hline Voice and & $-4.625 * * *$ & 1.503 & $-1.909 * *$ & $-2.074 * *$ \\
\hline Accountability & $(0.007)$ & $(0.977)$ & $(0.972)$ & $(0.849)$ \\
\hline Rule of Law & $\begin{array}{c}5.999 * * * \\
(0.720)\end{array}$ & $\begin{array}{l}-0.726 \\
(0.924)\end{array}$ & $\begin{array}{c}2.312 * * \\
(0.973)\end{array}$ & $\begin{array}{c}2.248 * * * \\
(0.799)\end{array}$ \\
\hline Election & $\begin{array}{c}0.331 * * * \\
(0.092)\end{array}$ & $\begin{array}{c}0.417 * * * \\
(0.060)\end{array}$ & $\begin{array}{c}0.399 * * * \\
(0.059)\end{array}$ & $\begin{array}{c}0.385 * * * \\
(0.059)\end{array}$ \\
\hline $\begin{array}{l}\text { Government } \\
\text { Effectiveness }\end{array}$ & $\begin{array}{c}-7.598 * * * \\
(0.560)\end{array}$ & $\begin{array}{l}-0.798 \\
(1.070)\end{array}$ & $\begin{array}{l}-0.071 \\
(1.053)\end{array}$ & -- \\
\hline $\begin{array}{l}\text { Regulatory } \\
\text { Quality }\end{array}$ & $\begin{array}{c}-8.082 * * * \\
(0.796)\end{array}$ & $\begin{array}{l}-1.551 \\
(0.946)\end{array}$ & $\begin{array}{l}-0.356 \\
(0.912)\end{array}$ & -- \\
\hline Conflict & $\begin{array}{l}-0.011 \\
(0.141)\end{array}$ & $\begin{array}{c}-0.167 * * \\
(0.077)\end{array}$ & $\begin{array}{l}-0.062 \\
(0.076)\end{array}$ & -- \\
\hline $\mathrm{N}$ & 1,744 & 1,744 & 1,744 & 1,744 \\
\hline Adjusted $\mathrm{R}^{2}$ & 0.77 & 0.53 & 0.49 & 0.62 \\
\hline F-statistic & 458.44 & 124.63 & 19.57 & 20.03 \\
\hline Prob $>$ F & 0.000 & 0.000 & 0.000 & 0.000 \\
\hline
\end{tabular}

Conflict was only significant in the entity-only fixed effects model and did not have the expected sign in any regression; the presence of a political conflict such as politically-motivated violence or terrorism should increase risk and therefore increase yields. However, the results indicate in Regression II that a month where at least one instance of politically-motivated violence or terrorism occurred, yields should 
decrease by 0.06 percentage points, or rather 6 basis points. This finding does not concur with the expectation that events sparking instability should increase yields.

Table 3 shows the regression results for the 10-year local currency-U.S. Treasury yield spread. Examining yield spreads though this lens creates a comparison of all countries' yields in the dataset to the U.S. Treasury yield, which tells much about each country's default risk. Regression V shows the results from the pooled OLS regression model. This model though not expected to be the preferred model was used as a comparison to the time and entity fixed effects models. Regression VI shows the regression results from a time and entity fixed effects model with all variables included. Regression VII shows results for the same time and entity fixed effects model, removing the statistically insignificant governance and political variables: Government Effectiveness, Regulatory Quality, and Political Event Shocks.

Growth is significant only in the pooled OLS model however it does have the expected sign on each coefficient. The coefficient on Growth from Regression V can be interpreted as the following: a onepercentage point increase in economic growth leads to about a 0.045 percentage point decrease in default risk, on average. Debt to GDP is highly significant in each regression, however only Regression VII provides the expected relationship to risk: as a country's government debt in relation to their GDP increases, yields should also increase through increased default risk. Regression VII shows that a one percentage point increase in the debt-to-GDP ratio will lead to a 0.022 percentage point increase in default risk. Inflation was not significant at any level in any regression in Table 2 . The likely reason for this fundamental variable to not show any significance is that since these are high-functioning emerging markets, inflation rates remain relatively stable and are therefore absorbed by the fixed effects. The Budget Balance and Policy Rate variables both have the expected relationships to risk as shown by the sign on their respective coefficients, and the results indicate both variables' strong significance. The exchange rate is also highly significant across all regressions in Table 2, but has the expected positive relationship with risk in Regression VII only. The federal funds rate is highly significant in each regression model, but it does not have the expected relationship with risk. The federal funds rate is directly linked to Treasury yields and should move along with them. However, an increase in the federal funds rate would directly increase the U.S. Treasury yield, which would in turn narrow the gap between U.S. Treasury yield and the local currency yield, indicating a reduction in risk. The Political Stability, Control of Corruption, and Voice and Accountability variables are all significant and have the expected relationship to risk in fixed effects regression models VI and VII. Rule of Law is significant each model but does not have the expected relationship with default risk. The results from Regression VII indicate a 1 percent increase in the Rule of Law score actually increases the default risk yield spread by 2.248 percentage points, which is not what theory or intuition would suggest. The Government Effectiveness, Regulatory Quality, and Conflict variables were eliminated form Regression VII due to their insignificance in the time and entity fixed effects model, Regression VI.

Table 4 provides an extension of the topic by examining local currency bond yields with different terms to maturity. By measuring the difference between the 10-year and 1-year bonds, and the difference between the 30-year and 10-year bonds, we can directly examine how each variable affects the level and slope of the yield curve. Here, a positive coefficient in either yield spread should indicate that the slope is steepening. Because of data availability, the number of countries and sample period were reduced. ${ }^{3}$ To examine level effects, Regressions VIII and IX in Table 4 report results from time and entity fixed effects models using the local currency 1-year and 30-year bond yields, respectively. Fixed effects regressions with all the governance variables included were conducted, but Government Effectiveness and Regulatory Quality were insignificant. Regressions VIII and IX report results with these variables excluded. 


\section{TABLE 3}

\section{REGRESSION RESULTS FOR YIELD CURVE SLOPE EFFECTS}

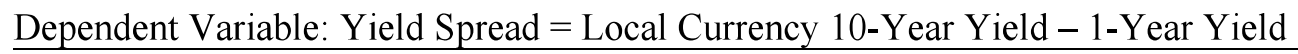

\begin{tabular}{|c|c|c|c|}
\hline & $\begin{array}{c}(\mathrm{V}) \\
\text { Pooled OLS }\end{array}$ & $\begin{array}{l}\quad(\mathrm{VI}) \\
\text { Entity \& Time } \\
\text { Fixed Effects }\end{array}$ & $\begin{array}{c}(\mathrm{VII}) \\
\text { Entity \& Time } \\
\text { Fixed Effects }\end{array}$ \\
\hline Growth & $\begin{array}{c}-0.045^{* * *} \\
(0.014)\end{array}$ & $\begin{array}{l}-0.006 \\
(0.007)\end{array}$ & $\begin{array}{l}-0.006 \\
(0.007)\end{array}$ \\
\hline Debt & $\begin{array}{c}-0.035 * * * \\
(0.002)\end{array}$ & $\begin{array}{c}-0.021 * * * \\
(0.006)\end{array}$ & $\begin{array}{c}0.022 * * * \\
(0.005)\end{array}$ \\
\hline Inflation & $\begin{array}{l}-0.015 \\
(0.015)\end{array}$ & $\begin{array}{l}-0.015 \\
(0.021)\end{array}$ & $\begin{array}{l}-0.016 \\
(0.021)\end{array}$ \\
\hline $\mathrm{CAB}$ & $\begin{array}{c}-0.176^{* * *} \\
(0.008)\end{array}$ & $\begin{array}{c}-0.056^{* * *} \\
(0.009)\end{array}$ & $\begin{array}{c}-0.056 * * * \\
(0.009)\end{array}$ \\
\hline Budget Balance & $\begin{array}{c}-0.131 * * * \\
(0.015)\end{array}$ & $\begin{array}{c}-0.086 * * * \\
(0.015)\end{array}$ & $\begin{array}{c}-0.086 * * * \\
(0.015)\end{array}$ \\
\hline Policy Rate & $\begin{array}{c}0.308 * * * \\
(0.027)\end{array}$ & $\begin{array}{c}0.345^{* * *} \\
(0.019)\end{array}$ & $\begin{array}{c}0.346 * * * \\
(0.018)\end{array}$ \\
\hline Exchange Rate & $\begin{array}{c}-00004^{*} \\
(0.000)\end{array}$ & $\begin{array}{c}-0.0003 * * * \\
(0.000)\end{array}$ & $\begin{array}{c}0.0003 * * * \\
(0.000)\end{array}$ \\
\hline Fed Funds Rate & $\begin{array}{c}-0.300 * * * \\
(0.025)\end{array}$ & $\begin{array}{c}-0.354 * * * \\
(0.070)\end{array}$ & $\begin{array}{c}-0.350 * * * \\
(0.070)\end{array}$ \\
\hline Elections & $\begin{array}{c}0.336 * * * \\
(0.092)\end{array}$ & $\begin{array}{c}0.399 * * * \\
(0.059)\end{array}$ & $\begin{array}{c}0.395 * * * \\
(0.059)\end{array}$ \\
\hline Political Stability & $\begin{array}{c}0.975 * * * \\
(0.174)\end{array}$ & $\begin{array}{c}-2.579 * * * \\
(0.260)\end{array}$ & $\begin{array}{c}-2.662 * * * \\
(0.233)\end{array}$ \\
\hline $\begin{array}{l}\text { Control of } \\
\text { Corruption }\end{array}$ & $\begin{array}{l}1.021^{*} \\
(0.554)\end{array}$ & $\begin{array}{c}-2.891 * * * \\
(0.516)\end{array}$ & $\begin{array}{c}-2.942 * * * \\
(0.442)\end{array}$ \\
\hline Voice and & $-4.761 * * *$ & $-1.909 * *$ & $-2.074 * *$ \\
\hline Accountability & $(0.338)$ & $(0.972)$ & $(0.849)$ \\
\hline Rule of Law & $\begin{array}{c}6.012 * * * \\
(0.722)\end{array}$ & $\begin{array}{c}2.312^{* *} \\
(0.973)\end{array}$ & $\begin{array}{c}2.248 * * * \\
(0.799)\end{array}$ \\
\hline $\begin{array}{l}\text { Government } \\
\text { Effectiveness }\end{array}$ & $\begin{array}{c}-7.647 * * * \\
(0.562)\end{array}$ & $\begin{array}{l}-0.071 \\
(1.053)\end{array}$ & -- \\
\hline $\begin{array}{l}\text { Regulatory } \\
\text { Quality }\end{array}$ & $\begin{array}{c}-7.912 * * * \\
(0.080)\end{array}$ & $\begin{array}{l}-0.356 \\
(0.912)\end{array}$ & -- \\
\hline Conflict & $\begin{array}{c}0.124 \\
(0.141) \\
\end{array}$ & $\begin{array}{l}-0.062 \\
(0.076) \\
\end{array}$ & -- \\
\hline $\mathrm{N}$ & 1,744 & 1,744 & 1,744 \\
\hline Adjusted $\mathrm{R}^{2}$ & 0.77 & 0.51 & 0.58 \\
\hline F-statistic & 484.17 & 198.27 & 16.57 \\
\hline Prob $>$ F & 0.00 & 0.00 & 0.00 \\
\hline
\end{tabular}


TABLE 4

REGRESION RESULTS FOR LEVEL AND SLOPE EFFECTS

\begin{tabular}{|c|c|c|c|c|}
\hline $\begin{array}{l}\text { Dependent } \\
\text { Variable }\end{array}$ & $\begin{array}{l}\text { (VIII) } \\
\text { 1-Year } \\
\text { Yield }\end{array}$ & $\begin{array}{l}\text { (IX) } \\
\text { 30-Year } \\
\text { Yield }\end{array}$ & $\begin{array}{c}(\mathrm{X}) \\
10-1 \text { Year } \\
\text { Yield Spread }\end{array}$ & $\begin{array}{c}\text { (XI) } \\
30-10 \text { Year } \\
\text { Yield Spread }\end{array}$ \\
\hline Growth & $\begin{array}{c}-0.026^{* *} \\
(0.011)\end{array}$ & $\begin{array}{l}-0.009 \\
(0.010)\end{array}$ & $\begin{array}{l}0.020^{*} \\
(0.010)\end{array}$ & $\begin{array}{c}0.007 \\
(0.101)\end{array}$ \\
\hline Debt & $\begin{array}{c}0.013 \\
(0.009)\end{array}$ & $\begin{array}{c}0.021^{* *} \\
(0.010)\end{array}$ & $\begin{array}{c}0.022 * * \\
(0.009)\end{array}$ & $\begin{array}{l}-0.018^{*} \\
(0.101)\end{array}$ \\
\hline Inflation & $\begin{array}{c}0.104 * * * \\
(0.033)\end{array}$ & $\begin{array}{c}0.415 * * * \\
(0.047)\end{array}$ & $\begin{array}{c}-0.128 * * * \\
(0.032)\end{array}$ & $\begin{array}{c}-0.116^{* *} \\
(0.048)\end{array}$ \\
\hline $\mathrm{CAB}$ & $\begin{array}{c}-0.040 * * * \\
(0.015)\end{array}$ & $\begin{array}{l}-0.033 \\
(0.025)\end{array}$ & $\begin{array}{l}-0.003 \\
(0.014)\end{array}$ & $\begin{array}{c}0.116^{* * *} \\
(0.026)\end{array}$ \\
\hline $\mathrm{BB}$ & $\begin{array}{l}-0.046^{*} \\
(0.028)\end{array}$ & $\begin{array}{c}-0.043 * * \\
(0.020)\end{array}$ & $\begin{array}{l}-0.048^{*} \\
(0.027)\end{array}$ & $\begin{array}{l}0.0002 \\
(0.020)\end{array}$ \\
\hline Policy Rate & $\begin{array}{c}0.588 * * * \\
(0.039)\end{array}$ & $\begin{array}{c}0.211 * * * \\
(0.018)\end{array}$ & $\begin{array}{c}-0.351 * * * \\
(0.038)\end{array}$ & $\begin{array}{c}-0.125^{* * * *} \\
(0.189)\end{array}$ \\
\hline Exchange Rate & $\begin{array}{c}0.001 * * * \\
(0.000)\end{array}$ & $\begin{array}{c}-0.00001 * * * \\
(0.000)\end{array}$ & $\begin{array}{c}-0.0002 * * * \\
(0.000)\end{array}$ & $\begin{array}{c}-0.0004 * * * \\
(0.0001)\end{array}$ \\
\hline U.S. Treasury* & $\begin{array}{c}1.283 \\
(2.727)\end{array}$ & $\begin{array}{c}3.770 * * * \\
(1.067)\end{array}$ & $\begin{array}{l}1.069 \\
(0.843)\end{array}$ & $\begin{array}{c}0.551 \\
(0.701)\end{array}$ \\
\hline Fed Funds Rate & $\begin{array}{l}-0.481 \\
(1.914)\end{array}$ & $\begin{array}{l}-0.986 \\
(0.623)\end{array}$ & $\begin{array}{c}0.374 \\
(3.000)\end{array}$ & $\begin{array}{c}2.013 * * \\
(0.809)\end{array}$ \\
\hline Political Stability & $\begin{array}{c}-6.086^{* * *} \\
(0.419)\end{array}$ & $\begin{array}{c}2.090 * * * \\
(0.624)\end{array}$ & $\begin{array}{c}4.353 * * * \\
(0.407)\end{array}$ & $\begin{array}{c}7.414 * * * \\
(0.637)\end{array}$ \\
\hline $\begin{array}{l}\text { Control of } \\
\text { Corruption }\end{array}$ & $\begin{array}{c}-2.581 * * * \\
(0.850)\end{array}$ & $\begin{array}{l}1.717^{* *} \\
(0.809)\end{array}$ & $\begin{array}{c}-2.010^{* *} \\
(0.827)\end{array}$ & $\begin{array}{c}4.560 * * * \\
(0.826)\end{array}$ \\
\hline Rule of Law & $\begin{array}{c}-4.201 * * \\
(1.656)\end{array}$ & $\begin{array}{l}-1.285 \\
(1.382)\end{array}$ & $\begin{array}{l}1.121 \\
(1.612)\end{array}$ & $\begin{array}{c}-2.216 \\
(1.411)\end{array}$ \\
\hline $\begin{array}{l}\text { Voice and } \\
\text { Accountability }\end{array}$ & $\begin{array}{c}11.034 * * * \\
(2.365)\end{array}$ & $\begin{array}{c}-7.523^{* * *} \\
(1.802)\end{array}$ & $\begin{array}{c}-4.536^{* *} \\
(2.302)\end{array}$ & $\begin{array}{c}-21.307^{* * *} \\
(1.839)\end{array}$ \\
\hline Conflict & $\begin{array}{l}-0.257 \\
(0.157)\end{array}$ & $\begin{array}{l}-0.013 \\
(0.072)\end{array}$ & $\begin{array}{c}0.234 \\
(0.163)\end{array}$ & $\begin{array}{c}0.160 * * \\
(0.173)\end{array}$ \\
\hline Elections & $\begin{array}{c}0.147 \\
(0.096)\end{array}$ & $\begin{array}{c}0.179 * * \\
(0.078)\end{array}$ & $\begin{array}{c}0.149 \\
(0.093)\end{array}$ & $\begin{array}{c}0.009 \\
(0.080)\end{array}$ \\
\hline $\mathrm{N}$ & 1,320 & 540 & 1,320 & 540 \\
\hline Adjusted $\mathrm{R}^{2}$ & 0.67 & 0.50 & 0.39 & 0.55 \\
\hline F-statistic & 18.55 & 7.03 & 5.75 & 8.70 \\
\hline Prob $>$ F & 0.00 & 0.00 & 0.00 & 0.00 \\
\hline
\end{tabular}

*U.S. Treasury represents the 1-year U.S. Treasury yield in column VIII, the 30-year U.S.

Treasury Yield in IX, the 10-1 year U.S. Treasury yield difference in X, and the 30-10 year U.S. Treasury yield difference in XI.

The results from Regressions X and XI indicate that an increase in the Political Stability score actually steepens the slope of the entire yield curve. The negative coefficient for Control of Corruption indicates a flattening of the short $(10-1$ year) end of the curve and a steepening of the long (30 - 10 year) end of the curve, suggesting an inversion of slope the yield curve. Increasing the Voice and Accountability score flattens the entire curve. The statistically significant and positive coefficient for Conflict in Regression XI suggests politically-motivated acts of violence only steepen the long end of the 
curve, while having no significant short term effects. Based on theories of term structure, these results suggest that institutional effectiveness and political events and stability affect not only the level of local currency yields, but also the slope of the yield curve. Moreover, despite the likelihood of high multicollinearity between our political and institutional measures, they are individually significant and have differential effects on local currency yields.

\section{CONCLUSIONS}

Our research suggests that political stability and institutional quality have a significant effect not only on local currency yields, but also on the slope of the yield curve in emerging markets. The Political Stability, Control of Corruption, and Voice and Accountability variables were consistently significant throughout the yield and default risk models. Rule of Law was also consistently significant across the 10year yield and default risk models; however, it had a positive relationship with yields though all of the governance index variables were predicted to have an inverse relationship. Government Effectiveness and Regulatory Quality were not statistically significant in the preferred fixed effects regressions in any model. This is perhaps due to the fact that the Government Effectiveness score most directly measures the quality of public goods and services, which does not have an explicit impact on yields or local currency bond market. Regulatory Quality directly evaluates the private sector development; therefore, this variable does not directly nor explicitly affect yields. While both contribute to the overall description of the quality and stability governments, they do not appear to significantly affect the bond market distinct from other governance variables. Elections have a consistently positive and statistically significant impact on 10-year and 30-year yields and default risk, but did not affect the short-term bonds or the slope of the yield curve. This result can be explained through knowing the nature and dynamic of risk in different durations; short-term bonds present much less risk than long-term bonds so the impact of party changing elections only has a significant impact on long-term risk. The occurrence of politicallymotivated conflict was primarily inconsistent, showing that individual occurrences of violence do not affect yields or risk as much as the probability of violence (as captured by the Political Stability score). The macroeconomic fundamentals variables were all as significant as expected and primarily contained the expected relationship with yields, default risk, and the yield curve.

This research contributes to future policy implications as the date was acquired with relative ease and the models easily replicated, given one's access to the data source and statistical software the panel of countries can be easily separated to assess each country individually as a time-series dataset. Given the flexibility of the data this model and its modifications prove to be a beneficial tool for investors making trade decisions whether one seeks involvement in a country-specific local currency bond market or the EM local currency bond market in its entirety.

This study provides a hub for future research as it opened many paths to explore. Since conflict and elections do not have instantaneous side-effects, it would be profitable to explore their lagged effect on yields and risk. To control for global economic health, perhaps a before-and-after analysis of the global financial crisis could be implemented to observe any behavioral changes in the market. To control for creditworthiness, perhaps including historical credit rating changes could prove a useful tool to assist in analyzing the probability of default.

\section{ENDNOTES}

1. Each country is scored on a series of questions relating to each governance category and then normalized on a scale with a mean of 0 and values ranging from -2.5 to +2.5 , where higher values relate to better outcomes. However, for ease of interpretation, the governance variables were all re-normalized to a scale from 0 to 100. In the regressions results which follow, these indices are measured in log levels.

2. Given the nature of panel data, there are unobservable time-invariant differences across countries, such as culture and social dynamics, that the governance variables are unable to capture. Aggregate time trends may also adversely influence the cross-country analysis. These may be controlled for using a time and 
entity (two-way) fixed effects model. Results from a Hausman test confirmed the appropriate model to use was a fixed effects model rather than a random effects model. A Wald test was then conducted which confirmed that there are time-specific fixed effects in addition to entity fixed effects that must be accounted for in the regressions presented in Tables 2-4.

3. The countries included in the $30-10$-year yield spread are: Brazil, Hungary, Indonesia, Mexico, Peru, Philippines, Russia, South Africa, South Korea, and Taiwan. The dates range from September 2012 to February 2017. The countries included in the 10 - 1-year yield spread are: Chile, Czech Republic, Hungary, Indonesia, Malaysia, Peru, Philippines, Poland, South Africa, South Korea, and Taiwan. The dates range from March 2007 to February 2017.

\section{REFERENCES}

Andritzky, J.R. (2012). Government bonds and their investors: What are the facts and do they matter? International Monetary Fund working paper no. 12/158.

Arslanalp, S., \& Tsuda, T. (2014). Tracking global demand for emerging market sovereign debt. IMF Economic Review, 62, 430-464.

Baldacci, E., Gupta, S., \& Mati, A. (2011). Political and fiscal risk determinants of sovereign spreads in emerging markets. Review of Development Economics, 15, 251-263.

Bank for International Settlements. (2016). Debt securities statistics [data file]. Retrieved from http://stats.bis.org/statx/srs/table/C1?c=\&p=20161

Burger, J., \& Warnock, F. (2006). Local currency bond markets. National Bureau of Economic Research working paper no. 12552 .

Burger, J., Warnock, F., \& Cacdac, V. (2012). Emerging local currency bond markets. Financial Analysts Journal, 68(4), 73-93.

Calvo, G.A., \& Talvi, E. (2008). Sudden stops, financial factors and economic collapse in Latin America: learning from Argentina and Chile. In N. Serra \& J. Stiglitz (Eds.), The Washington consensus reconsidered: Towards a new global governance (Initiative for policy dialogue series). New York, NY: Oxford University Press.

Ebeke, C., \& Lu, Y. (2015). Emerging market local currency bond yields and foreign holdings -- A fortune or misfortune? Journal of International Money and Finance, 59, 203-219.

Eichengreen, B., Hausmann, R., \& Panizza, U. (2008). Currency mismatches, debt intolerance, and original sin: Why they are not the same and why it matters. In P. Collier \& J. Gunning (Eds.), Globalization and poverty (pp. 498-546). Cheltenham, U.K.: Elgar.

Eichler, S. (2014). The political determinants of sovereign bond yield spreads. Journal of International Money and Finance, 46, 82-103.

Ferrari, F. \& Rolfini, R. (2008). Investing in a dangerous world: A new political risk index. SACE Group Working Paper no. 5.

Ferrucci, G. (2003). Empirical determinants of emerging market economies' sovereign bond spreads. Bank of England working paper no. 205.

International Monetary Fund. (2016, December 14). Development of local currency bond markets. Retrieved from https://www.imf.org/external/np/g20/pdf/2016/121416.pdf.

Jaramillo, L., \& Weber, A. (2013). Bond yields in emerging economies: It matters what state you are in. Emerging Markets Review, 17, 169-185.

Miyajima, K., Mohanty, M., \& Chan, T. (2015). Emerging market local currency bonds: Diversification and stability. Emerging Markets Review, 22, 126-139.

Peiris, S. J. (2013). Foreign participation in local currency bond markets of emerging economies. Journal of International Commerce, Economics and Policy, 4(3), 1-15. 


\section{APPENDIX}

\section{DEFINITIONS AND SOURCES OF VARIABLES}

\begin{tabular}{|c|c|c|}
\hline Variable & Definition & Source \\
\hline Yield & $\begin{array}{l}\text { Generic 10-year, 1-year, or 30-year local currency } \\
\text { government bond yield, yield to maturity }\end{array}$ & Bloomberg \\
\hline $\begin{array}{l}\text { Industrial } \\
\text { Production }\end{array}$ & $\begin{array}{l}\text { Measured as a month-on-month percent change. } \\
\text { Captures economic growth on a more granular basis } \\
\text { than GDP, which is reported quarterly. }\end{array}$ & Bloomberg, OECD \\
\hline Rate & Central bank policy rates & Bloomberg \\
\hline Inflation & $\begin{array}{l}\text { Measured as month-on-month percent change in the } \\
\text { consumer price index (CPI) }\end{array}$ & $\begin{array}{l}\text { Bloomberg, IMF World } \\
\text { Economic Outlook } \\
\text { Database }\end{array}$ \\
\hline Exchange Rate & Local currency to USD exchange rate & Bloomberg \\
\hline Policy Rate & Central bank policy rates & Bloomberg \\
\hline Fed Funds Rate & Federal funds rate & Bloomberg \\
\hline $\begin{array}{l}\text { U.S. Treasury } \\
\text { yield }\end{array}$ & $\begin{array}{l}\text { Generic 10-year, 1-year, or 30-year U.S. Treasury } \\
\text { yields }\end{array}$ & Bloomberg \\
\hline Debt & $\begin{array}{l}\text { Government debt-to-GDP Ratio. Measures debt as a } \\
\text { percent of GDP }\end{array}$ & Bloomberg \\
\hline $\mathrm{CAB}$ & Current account balance as a percent of GDP & Bloomberg \\
\hline Budget Balance & Budget balance measured as a percent of GDP & Bloomberg \\
\hline $\begin{array}{l}\text { Political Stability } \\
\text { (PS) }\end{array}$ & $\begin{array}{l}\text { Index that measures each country's overall political } \\
\text { stability and absence of politically-motivated violence } \\
\text { or terrorism. }\end{array}$ & $\begin{array}{l}\text { Worldwide Governance } \\
\text { Indicators, World Bank }\end{array}$ \\
\hline $\begin{array}{l}\text { Regulatory } \\
\text { Quality (RQ) }\end{array}$ & $\begin{array}{l}\text { Index that captures a government's ability to create } \\
\text { laws that promote private sector development. }\end{array}$ & $\begin{array}{l}\text { Worldwide Governance } \\
\text { Indicators, World Bank }\end{array}$ \\
\hline $\begin{array}{l}\text { Government } \\
\text { Effectiveness } \\
\text { (GE) }\end{array}$ & $\begin{array}{l}\text { Index that captures the quality of public and civil } \\
\text { service, and the formulation and implementation of } \\
\text { government policies. }\end{array}$ & $\begin{array}{l}\text { Worldwide Governance } \\
\text { Indicators, World Bank }\end{array}$ \\
\hline Rule of Law (RL) & $\begin{array}{l}\text { Index that captures the degree to which citizens abide } \\
\text { by laws as well as the quality of property rights and law } \\
\text { enforcement. }\end{array}$ & $\begin{array}{l}\text { Worldwide Governance } \\
\text { Indicators, World Bank }\end{array}$ \\
\hline $\begin{array}{l}\text { Voice and } \\
\text { Accountability } \\
\text { (VA) }\end{array}$ & $\begin{array}{l}\text { Index that captures the extent to which citizens are able } \\
\text { to participate in electing government officials and their } \\
\text { degree of free speech, free media, and free expression. }\end{array}$ & $\begin{array}{l}\text { Worldwide Governance } \\
\text { Indicators, World Bank }\end{array}$ \\
\hline $\begin{array}{l}\text { Control of } \\
\text { Corruption (CC) }\end{array}$ & $\begin{array}{l}\text { Index that captures the extent to which government } \\
\text { power is used for private gain. }\end{array}$ & $\begin{array}{l}\text { Worldwide Governance } \\
\text { Indicators, World Bank }\end{array}$ \\
\hline Conflict & $\begin{array}{l}\text { Binary variable that captures the presence of a terrorist } \\
\text { attack or military uprising. }\end{array}$ & $\begin{array}{l}\text { Political Instability Task } \\
\text { Force }\end{array}$ \\
\hline Elections & $\begin{array}{l}\text { Binary variable indicating the presence of a presidential } \\
\text { or parliamentary election in which the political party } \\
\text { changes. }\end{array}$ & $\begin{array}{l}\text { Database of Political } \\
\text { Institutions, World Bank }\end{array}$ \\
\hline
\end{tabular}

